Anna Ziółkowska-Juś

Uniwersytet im. Adama Mickiewicza, Poznań

ORCID: 0000-0001-9757-9095

e-mail: annazio@amu.edu.pl

\title{
Uczucia estetyczne i poznanie integralne W perspektywie estetyki pragmatycznej Johna Deweya
}

W tradycji zachodniej oddzielanie sfery poznawczej od sfery uczuć opiera się na kultywowanych dualizmach typu: umysł-ciało, rozumuczucia, podmiot-przedmiot. Chociaż sięga początkami myśli starożytnych filozofów, swoje najpełniejsze ugruntowanie odnalazło w filozofii kartezjańskiej, a następnie w filozoficznym pozytywizmie, scjentyzmie i emotywizmie. W kulturze, w której prym wiodą cele związane z nauka, postępem cywilizacyjnym i technicznym, często zaniedbuje się rozwój emocjonalny człowieka. Sfera umysłowa jest w niej często uważana za ważniejszą od sfery emocjonalnej ${ }^{1}$. Pomimo przeprowadzenia w XX wieku licznych badań wskazujących na silny związek pomiędzy rozwojem uczuć i inteligencją poznawcza, trudno oprzeć się wrażeniu, że w szkołach i na uniwersytetach wciąż pokutuje przekonanie o ich dwutorowości ${ }^{2}$. W procesie poznawczym uczucia są często traktowane

${ }^{1}$ Zob. Stanley I. Greenspan, Beryl Lieff Benderly, Rozwój umysłu. Emocjonalne podstawy inteligencji, przeł. Małgorzata Koraszewska (Poznań: Rebis, 2000), 10 oraz Kazimierz Dąbrowski, Zdrowie psychiczne, (Warszawa: PWN, 1981), 158.

2 W latach dziewięćdziesiątych powstało na temat związku uczuć i emocji wiele prac, m.in. Greenspan, Benderly Rozwój umystu; Antonio Damasio, Tajemnica świadomości: Ciało i emocje współtworza świadomość, przeł. Maciej Karpiński (Poznań: Rebis, 2000); Antonio Damasio, Błąd Kartezjusza: emocje, rozum i ludzki mózg, przeł. Maciej Karpiński (Poznań: Rebis, 2002); Joseph E. Le Doux, Mózg emocjonalny. Tajemnicze podstawy życia emocjonalnego, przeł. Andrzej Jankowski (Poznań: Media Rodzina, 2000); 
jedynie instrumentalnie albo całkowicie lekceważone. Nierzadko w poznaniu naukowym, pomimo jego dużej precyzji i dokładności (dającej się niekiedy porównać do precyzji tzw. sztucznej inteligencji) brakuje świeżości i twórczości, które mogą wnieść dopiero uczucia. Często się zdarza, że silne emocje towarzyszą poznaniu intelektualnemu, ale go bezpośrednio nie dotyczą. Emocje pojawiają się na przykład w związku z towarzyszącymi wiedzy władza, uznaniem, oceną i sukcesem albo $\mathrm{z}$ wygraną pieniężną ( $\mathrm{z}$ czym mamy do czynienia także $\mathrm{w}$ teleturniejach). Nie są jednak bezpośrednio wprzęgnięte w proces poznawczy.

Celem niniejszych rozważań jest wskazanie z perspektywy pragmatyzmu Johna Deweya roli, jaką w poznaniu integralnym pełnią uczucia. Rozwijana przeze mnie w różnych tekstach koncepcja poznania integralnego $^{3}$ jest inspirowana refleksją Johna Deweya, Richarda Shustermana, Richarda Rorty'ego, Marka Johnsona, a także poglądami filozofów, których nie da się usytuować w nurcie pragmatyzmu, np. Michela Foucaulta, Thomasa Kuhna, Hansa-Georga Gadamera, Maurice'a Merlau-Ponty'ego, Wolfganga Welscha. Niniejszy artykuł dotyczy tych inspiracji, które pochodzą od Deweya i odnoszą się do uczuciowego aspektu poznania integralnego. Autor Sztuki jako doświadczenia nie posługiwał się sformułowaniem „poznanie integralne”. Pisał o doświadczeniu integralnym, które odnosił do sfery szerszej niż poznawcza. Według Deweya doświadczenia integralne, w przeciwieństwie do doświadczeń nieintegralnych, posiadają aspekty estetyczne. Doświadczenie estetyczne staje się ich integralną częściąa . Wprowadzam kategorię poznania integralnego na oznaczenie poznania, które ma charakter estetyczny, czyli angażuje nie tylko wyizolowany z kontekstu doświadczenia umysł, ale również uczucia, wyobraźnię, zmysły, intuicję w ich niepodzielnej jedności.

Warto na wstępie przybliżyć główne założenia przyświecające koncepcji poznania integralnego. Po pierwsze jest ono ukierunkowane na cele poznawcze, ale realizuje je zarówno w poznawczy (związany z określoną metodologią), jak i estetyczny sposób. Istotną rolę pełnią

Daniel Goleman, Inteligencja emocjonalna (Poznań: Media Rodzina, 1997); Natura emocji. Podstawowe zagadnienia, red. Paul Ekman, Richard J. Davidson, przeł. Bogdan Wojciszke (Gdańsk: Gdańskie Wydawnictwo Psychologiczne, 1999), 158-204.

${ }^{3}$ Koncepcję poznania integralnego rozwijałam $w$ następujących artykułach: Anna Ziółkowska-Juś, „Rola doświadczenia estetycznego w poznaniu integralnym. Ku Deweyowskim inspiracjom", Estetyka i krytyka 42, 3 (2016): 219-244, a także Anna Ziółkowska-Juś, „Świadomość i poznanie integralne. W kręgu inspiracji pragmatyzmem Johna Deweya", Filo-Sofija 43, 4 (2018): 37-55.

${ }^{4}$ Do ważniejszych polskich opracowań koncepcji doświadczenia estetycznego w estetyce pragmatycznej należą: Krystyna Wilkoszewska, Sztuka jako rytm życia. Rekonstrukcja filozofii sztuki Johna Deweya (Kraków: Universitas, 2003); Dorota Koczanowicz, Doświadczenie sztuki, sztuka życia. Wymiary estetyki pragmatycznej (Wrocław: Wydawnictwo Dolnośląskiej Szkoły Wyższej Edukacji TWP, 2008); Sebastian Stankiewicz, Estetyka pragmatyczna - projekt otwarty (Kraków: Universitas, 2012). 
w nim czynniki wykraczające poza intelekt. Dla powodzenia poznania integralnego czynniki estetyczne (uczucia, zmysły, intuicja, wyobraźnia) nie są przypadkowe ani zakłócające, ale stanowią jego niezbywalny, konstruktywny aspekt. Co więcej, domagają się kształcenia. Po drugie poznanie integralne nie pretenduje do bycia "zwierciadłem natury" Jego punktem wyjścia i dojścia nie jest „oczyszczone” intelektualne doświadczenie, ale doświadczenie potoczne. Wzbogaca ono doświadczenie potoczne i wznosi je na wyższy poziom. Ma ono charakter twórczy, hermeneutyczny, interpretacyjny. Wiąże się z ponowoczesnym przeświadczeniem, że rzeczywistość nie ma trwałych, metafizycznych fundamentów, ale jest z natury swej dynamiczna, procesualna, zmienna, podatna na modelowanie. Ten "estetyczny non-fundamentalizm” i związana z nim estetyzacja epistemologiczna wymagają oparcia poznania na takim rodzaju doświadczenia, które ma charakter integralny i estetyczny ${ }^{6}$. Zarazem jednak poznanie integralne nie wpisuje się bez zastrzeżeń w nurt konstruktywistyczny (reprezentowany w filozofii na przykład przez Friedricha Nietzschego i Richarda Rorty'ego), gdyż tworzenie staje się $\mathrm{w}$ nim odkrywaniem. Trudno w nim przeprowadzić klarowną granicę pomiędzy podmiotem i przedmiotem, wnętrzem i zewnętrzem, tym, co subiektywne, i tym, co obiektywne. Po trzecie tego typu poznanie może dokonywać się $\mathrm{w}$ ramach instytucji albo poza nimi. Nie jest ono zarezerwowane dla jakiejś konkretnej dziedziny wiedzy. Po czwarte poznanie integralne nie jest czymś danym, ale zadanym. Jest ono zarazem kształtowane i kształtujące. Można przyczyniać się do jego kształtowania między innymi poprzez pracę z uczuciami, ale i ono samo kształtuje osobę poznająca, pogłębiając jej doświadczenia. Po piąte poznanie integralne jest pożądane, gdyż prowadzi nie tylko do owocnych wyników poznawczych, ale również przyczynia się do całościowego rozwoju osoby poznającej (jej satysfakcji i spełnienia) oraz rozwoju jej otoczenia. Celem stają się $\mathrm{w}$ nim nie tylko wyniki badawcze, ale również droga, która do nich wiedzie, oraz osoba poznająca i jej otoczenie.

Dewey nie poświęcił estetycznemu wymiarowi poznania osobnego studium. Zagadnienie to pojawia się w wielu tekstach filozofa (zwłaszcza w Psychologii, Jak myślimy?, Doświadczeniu i naturze, Sztuce jako doświadczeniu), jednak domaga się interpretacji i opracowania. Moim zdaniem koncepcja poznania integralnego zawiera się implicite $\mathrm{w}$ rozważaniach Deweya poświęconych innym, rozwijanym przez pragmatystę zagadnieniom. Zadaniem, jakie przed sobą stawiam (w tym i innych tekstach), jest wydobycie, wyeksponowanie tej koncepcji z jego rozważań, a także

${ }^{5}$ Zob. Richard Rorty, Filozofia a zwierciadło natury, przeł. Michał Szczubiałka (Warszawa: Wydawnictwo KR, 2013).

${ }^{6}$ Zob. Wolfgang Welsch, Estetyka poza estetyka. O nowa postać estetyki, przeł. Katarzyna Guczalska (Kraków: Universitas, 2005). 
dokonanie jej rekontekstualizacji. W niniejszym artykule, podążając za Deweyem, pragnę pokazać, jak i dlaczego doświadczenie estetyczne może posłużyć za wzorzec i podstawę dla sfery poznawczej w aspekcie uczuciowym. Stawiam tezę, że uczucia charakterystyczne dla doświadczenia estetycznego są istotne również dla poznania, gdyż przyczyniają się do jego integralności. Rekonstrukcje koncepcji estetycznej oraz koncepcji uczuć Deweya, których dokonuję w tekście, mają na celu wykazanie tej tezy.

W pierwszej części rozważań wskazuję za Deweyem na zapomniane w kulturze zachodniej pokrewieństwo doświadczenia estetycznego i poznania intelektualnego, w drugiej - naświetlam znaczenie uczuć w pragmatyzmie Deweya, natomiast w trzeciej - specyfikę wyróżnionych przez niego uczuć estetycznych. Zadaniem czwartej części jest pokazanie, jak i dlaczego uczucia estetyczne mogą przyczynić się do integralności poznania.

\section{Pokrewieństwo doświadczenia estetycznego i poznania integralnego}

Dewey odrzuca utrwalone kulturowo granice pomiędzy sztuką i innymi rodzajami doświadczeń, sytuując źródło tego, co estetyczne, w zwyczajnych przejawach życia ${ }^{7}$. Dla filozofa sztuką nie są wyizolowane przedmioty, ale doświadczenie. Ma ona zatem charakter procesualny. Filozof znacząco rozszerza zainteresowania estetyki, otwierając ją na zróżnicowane sfery życia, na przykład poznawcze, moralne i inne. Jego zdaniem samo życie może być sztuką jeśli będzie przeżywane estetycznie. Działalność artystyczna jest doświadczeniem wzorcowym, które uczy nas pełniejszego i bardziej satysfakcjonującego doświadczania otaczającej rzeczywistości ${ }^{8}$. W tym ujęciu sztuka polega na zintegrowanym sposobie doświadczania otaczającego nas świata. Jej integralność wiąże się z tym, że angażuje ona człowieka w jego aspekcie cielesnym, zmysłowym, uczuciowym i myślowym. Podmiotem sztuki nie jest doświadczający ani to, co doświadczane, ale samo doświadczenie'. Rodzi się ona z wzajemnej dynamiki doznawania i działania, jaka zachodzi pomiędzy organizmem i otoczeniem. Nie ma w niej dualizmów typu: umyst-ciało, podmiot-przedmiot, zewnętrzne-wewnętrzne, obiektywne-subiektywne, środki-cele, sztuka-życie itp. Dewey odrzuca zwłaszcza zako-

7 John Dewey, Sztuka jako doświadczenie, przeł. Andrzej Potocki (Warszawa-Kraków-Gdańsk: Zakład Narodowy im. A. Ossolińskich, 1975), 15.

8 Zob. tamże, 16.

9 Tamże, 340. 
rzeniony w zachodnim myśleniu przesąd o dualizmie umysłu i ciała ${ }^{10}$. Dualizm ten był jedną z przyczyn antagonizowania odczuwania i myślenia oraz sfer estetycznej i poznawczej. Tymczasem rozum nigdy nie działa w izolacji, ale jest warunkowany przez sferę cielesną (uczuciowa, zmysłową) i kontekst, w którym żywy ustrój jest usytuowany. Umysł wyewoluował z natury, a każda próba oddzielenia go od naturalnych, żywotnych soków może być jedynie pozorna i zarazem destrukcyjna dla doświadczenia i osoby doświadczającej.

Dewey nie koncentruje się zbytnio na specyficznych treściach doświadczeń. Rozróżnia wprawdzie doświadczenia estetyczne, poznawcze, moralne i codzienne ze względu na ich treści i stawiane sobie przez nie cele. Skupia się jednak na tym, co im wspólne i co przesądza o ich estetyczności, czyli na formie (,jjak” doświadczenia). W związku z tym rozróżnia doświadczenia integralne i nieintegralne. Jest to zarazem rozróżnienie pomiędzy sztuką i nie-sztuką. Wśród doświadczeń integralnych rozróżnia natomiast doświadczenie rzeczywiste (an experience) i „czyste” doświadczenie estetyczne (aesthetic experience). Doświadczenie rzeczywiste realizuje pozaestetyczne cele w estetyczny sposób. Może mieć ono charakter codzienny, poznawczy, moralny i inny. Natomiast głównym celem „czystego" doświadczenia estetycznego jest występująca w nim jakość estetyczna. "Czyste" doświadczenie estetyczne jest udziałem zarówno twórcy, jak i odbiorcy. W perspektywie pragmatyzmu Deweyowskiego rozróżnienie na proces twórczy i odbiorczy ulega zamazaniu. Zdaniem Deweya doświadczenie estetyczne występuje bądź osobno (w „czystej” postaci), bądź jako składnik doświadczenia rzeczywistego. Poznanie, podobnie jak inne rodzaje doświadczeń, może być zarówno integralne („rzeczywiste”), jak i nieintegralne. Poznanie integralne zawiera w sobie doświadczenie estetyczne.

Dewey wskazuje na wspólne źródło sfery poznawczej i estetycznej, jakim jest proces życia, czyli bezpośrednie oddziaływanie organizmu i otoczenia. Zdaniem Deweya różne doświadczenia człowieka mają „wspólne wzory" w związku z tym, że podlegają wspólnym rytmom przyrody, będącym źródłem ich formy. Pisze, że:

Bezpośrednim lub pośrednim źródłem wszelkiego doświadczenia jest wzajemne współdziałanie otoczenia i ustroju; to z otoczenia wywodzą się ograniczenia, opory, ponaglenia i stany równowagi, które przy zetknięciu się we właściwy sposób z energią ustroju ustanawiają formę.

10 Tamże, 322. Zob. też Richard Shusterman, Odnowienie somatycznej refleksji. Filozofia ciało - umystu Johna Deweya, w: Richard Shusterman, Świadomość ciała. Dociekania z zakresu somaestetyki, przeł. Wojciech Małecki, Sebastian Stankiewicz (Kraków: Universitas, 2010), 239-284. 
Rytm jest tą pierwszą charakterystyczną cechą otaczającego świata, jaka umożliwia istnienie formy artystycznej ${ }^{11}$.

Rytm oddechu, brania i dawania, wzlotu i spoczynku przenika różne rodzaje ludzkiej aktywności. Zainteresowanie rytmami łączy między innymi sztukę i poznanie. Jak zauważa Dewey, w starożytnej Grecji: „obie dziedziny nazywano techne. Dzieła filozoficzne pisano wierszem, a wysiłek wyobraźni spowodował, że świat stał się kosmosem"12.

Sztuka i poznanie pochodzą zatem z tego samego źródła, jakim jest proces życia, i charakteryzują się podobną formą ekspresji. Zarówno sztuka, jak i poznanie biorą początek z odczucia pewnego braku, napięcia bądź/i oporu, jaki pojawia się w związku z oddziaływaniem środowiskowych energii na ustrój i jego przeżycia. Rozwój życia wymaga chwilowych zaburzeń rytmu, co umożliwia przejście do stanu szerszej równowagi: „Chwila przejścia od zaburzeń do harmonii jest właśnie ta w której życie staje się najintensywniejsze [...] W świecie całkowitego zamętu nie dałoby się nawet walczyć z istniejącymi warunkami. Świat zbudowany na modłę naszego daje chwile spełnienia, które znaczą doświadczenie rytmem miarodajnych przerw"13. Z pokonywania trudności, oporów i napięć, jakie powoduje nacisk zewnętrznych warunków środowiskowych na uwewnętrznione przeżycia, rodzi się ekspresja ${ }^{14}$. Nie jest ona zwykłą odpowiedzią na bodźce, gdyż wiąże się z poszukiwaniem środków wyrazu, w które dopiero wcielić by się mogły doświadczane znaczenia. Na przykład malarz używa barw, muzyk dźwięków, a poeta słów. Natomiast uczony pracuje w materii słów, znaków formalnych, idei, pojęć. Do formalnych cech twórczej ekspresji należą: napięcie pomiędzy ustrojem a otoczeniem, kumulacja energii, zachowanie i stopniowe wyzwalanie energii, oczekiwanie i spełnienie. Twórcza ekspresja w sztuce i poznaniu ma jakościowo zbliżony charakter. Pod wpływem ekspresji powstaje nowy przedmiot ekspresyjny, który przekształca zarówno osobę doświadczająca, jak i jej otoczenie. Chociaż sztuka i poznanie wiążą się z pewnymi trudnościami, napięciami i oporami, to jednak rodzą one poprzez ekspresję pewien rodzaj współbrzmienia pomiędzy tym, co wydarza się w teraźniejszości, i przeszłymi doświadczeniami ${ }^{15}$. Dzięki temu rodzi się „przedmiot ekspresyjny”, będący re-

11 Dewey, Sztuka jako doświadczenie, 178.

12 Tamże, 180.

13 Tamże, 24.

14 Słowo „ekspresja” pochodzi od łacińskiego exprimere, oznaczającego „wyciskanie”, „wytłaczanie” i „wypychanie”. Dewey pisze: „Bez ciśnienia, bez kompresji nie ma ekspresji i nic nie może być wyrażone. Niepokój wskazuje nam miejsce, gdzie wewnętrzne odruchy i kontakty $\mathrm{z}$ otoczeniem $\mathrm{w}$ faktach lub pojęciach spotykają się i wywołują ferment". Tamże, 83.

15 Tamże, 81. 
zultatem twórczej aktywności. Ekspresja jest twórczą odpowiedzią na związaną z trudnościami i napięciami sytuację. Zarówno w sztuce, jak i w poznaniu komunikuje ona znaczenia.

Poznanie integralne, podobnie jak doświadczenie estetyczne, nie jest czymś danym, ale zadanym. Oba rodzaje doświadczeń są celowe, wewnętrznie scalone, uporządkowane i kumulatywne. Angażują one rozum, zmysły, uczucia, świadomość, wyobraźnię i intuicję w ich niepodzielnej jedności. Występuje w nich zintegrowanie środków i celów. Posiadają scalającą je jakość estetyczną. Charakteryzują się również świadomością związków pomiędzy doznaniem i działaniem, a także zależności pomiędzy przeszłym doświadczeniem, przyszłymi projektami i aktualnie doświadczaną sytuacją. Oba rodzaje doświadczeń dążą do spełnienia, a ich konsekwencją jest między innymi satysfakcja osoby doświadczającej.

Warto również wskazać na występujące pomiędzy "czystym" doświadczeniem estetycznym i poznaniem integralnym różnice. Poznanie integralne realizuje zarówno cele poznawcze, jak i estetyczne. Te drugie są podporządkowane pierwszym. Natomiast cel doświadczenia estetycznego tkwi w nim samym. Różnica pomiędzy tymi dwoma aktywnościami polega również na tym, że w „czystym” doświadczeniu estetycznym znaczenia wcielają się $\mathrm{w}$ środki wyrazu bez pośrednictwa pojęć, natomiast $\mathrm{w}$ poznaniu integralnym znaczenia (chociaż również domagają się bezpośredniego odczucia zmysłowego) najczęściej są zapośredniczone przez pojęcia ${ }^{16}$. Środki wyrazu, jakimi posługuje się filozof bądź uczony (znaki werbalne, liczby, słowa) są najczęściej oderwane od celów jego działań. Stąd też w działalności poznawczej istnieje nieustanne ryzyko rozdzielenia środków i celów. Natomiast w sztuce nie ma możliwości rozdzielenia pomiędzy środkami wyrazu a celami. Nie ma utworu muzycznego bez dźwięków ani obrazu bez barw. Środki wyrazu, w które zostały wcielone znaczenia, same stają się celem ${ }^{17}$. Ekspresja w sztuce oznacza więc zarówno czynność, jak i wynik tej czynności. W poznaniu pojęciowym funkcjonalny dualizm podmiot-przedmiot jest nieuchronny, co jednak nie wyklucza bezpośredniego (jakościowego, estetycznego) odczuwania słów, idei, atmosfery emanującej z otaczającego środowiska badacza i badanych przedmiotów. W obu rodzajach doświadczeń istotnej wagi nabierają uczucia.

${ }^{16}$ O tym, jak jest możliwe pogodzenie zapośredniczenia znaczeń przez pojęcia z ich bezpośrednim odczuciem, pisałam w artykule „Rola doświadczenia estetycznego w poznaniu integralnym. Ku Deweyowskim inspiracjom”.

17 Zob. Dewey, Sztuka jako doświadczenie, 78-79. 


\section{Charakterystyka uczuć w perspektywie pragmatyzmu Deweya}

W książce Sztuka jako doświadczenie pojawia się wiele konstatacji dotyczących uczuć i ich roli w czystym doświadczeniu estetycznym i doświadczeniu rzeczywistym (również poznawczym). Zanim przejdziemy do koncepcji uczuć estetycznych, zwróćmy uwagę na to, jak Dewey definiuje uczucia w ogóle. Warto dodać, że tezy Deweya dotyczące uczuć są w przeważającej mierze zgodne z głosami neurologów (na przykład Josepha LeDoux, Richarda Davidsona, Antoniego Damasio), co jest istotne, gdyż pokazuje aktualność jego koncepcji w kontekście najnowszych badań naukowych. Filozofia pragmatyczna przywiązuje dużą wagę do metod i wyników nauk empirycznych, a także zgodności własnych badań z tymi wynikami. Stąd też w rozdziale pojawią się między innymi nawiązania do koncepcji wymienionych neurologów.

Dewey odróżnia uczucie od spontanicznego odruchu ${ }^{18}$. W przeciwieństwie do odruchu, będącego reakcją na jakiś bodziec, uczucie jest związane ze znaczeniem i wartościa, nadanymi jakimś przedmiotom, wydarzeniom, sprawom. Inaczej niż w przypadku odruchowej reakcji emocjonalnej (na przykład grymasu twarzy albo odskoczenia), zakłada ono świadomość i ukierunkowanie ku czemuś. Ma zatem charakter celowy i intencjonalny. Aby odruchy (na przykład nerwowe podskoczenie albo rumieniec na twarzy) nabrały charakteru uczuciowego, muszą wiązać się z jakimś ustosunkowaniem się do sytuacji, której są częścią a także do przedmiotów i spraw, na które są nakierowane: „Odruch strachu staje się emocjonalnym stanem lęku dopiero, kiedy okaże się, że istnieje rzeczywiste zagrożenie, któremu trzeba stawić czoła lub przed nim uciec. Rumieniec zmienia się w uczucie wstydu, dopiero, kiedy człowiek łączy w myśli jakiś swój postępek z krytyczną oceną swojej osoby przez kogoś innego"19. Pobudzenie fizjologiczne prowadzi do nadania znaczeń i oceny źródła pobudzenia, co dopiero wywołuje określone uczucie ${ }^{20}$.

18 Tamże, 53-54. Mark Johnson w książce Znaczenie ciała: estetyka rozumienia ludzkiego, przeł. Jarosław Płuciennik (Łódź: Wydawnictwo Uniwersytetu Łódzkiego, 2015) dostrzega zgodność tezy Deweya dotyczącej uczuć z badaniami (przeprowadzonymi w oparciu o współczesne technologie neuroobrazowania fMRI i PET) współczesnych neurologów - Antoniego Damasio i Josepha LeDoux. Pisze na ten temat również Sebastian Stankiewicz w książce Estetyka - projekt otwarty, 192-193.

19 Dewey, Sztuka jako doświadczenie, 54.

${ }^{20} \mathrm{O}$ związku uczuć z ciałem i wartościowaniem sytuacji pisze również Antonio Damasio: „Uczucia pozwalają nam obserwować procesy rozgrywające się w naszym ciele w zestawieniu z obrazami tego, co dzieje się na zewnątrz. Dzięki temu modyfikują one nasze ogólne pojęcie o zewnętrznych sytuacjach i obiektach i wartościują ich obrazy jako dobre lub złe, przyjemne lub bolesne", Damasio, Błąd Kartezjusza, 184. 
Uczucia zależą od tego, jakie znaczenie i wyjaśnienie nadamy stanowi pobudzenia ${ }^{21}$.

Uczucia nie są zamknięte w jaźni, wyjąwszy uczucia patologiczne (różnego rodzaju złudzenia), ale są zawsze nakierowane na wydarzenia i przedmioty: „uczucie dotyczy czegoś obiektywnego, co istnieje w rzeczywistości lub w pojęciach, ku czemuś się kieruje i od czegoś zależy. Uczucie włącza się w jakąś sytuację, której wynik jest niepewny i która w sposób żywotny dotyczy jaźni poruszanej przez uczucie"22. Zdaniem Deweya w uczuciu jaźń przenika się z obiektywnymi warunkami. Nie ma między nimi rozdzielenia. Uczucie nie sytuuje się ani po stronie jaź$\mathrm{ni}$, ani po stronie przedmiotu, ale $\mathrm{w}$ przestrzeni relacyjnej między nimi ${ }^{23}$. Uczucie dotyczy całej doświadczanej sytuacji, wiążąc ją wybijającą się na czoło jakością.

Uczucie zawsze jest konkretne i własne. Nie ma czegoś takiego jak „lęk w ogóle”. W doświadczeniu uczucie nie ma charakteru ogólnego i neutralnego, ale zawsze jest zabarwione jakością przedmiotu, którego dotyczy. Uczucie nie ujawnia się wprost, ale przez relację jaźni z obiektem, którą jakoś zabarwia i przenika. Pojęciem uogólnionego uczucia możemy operować jedynie w celach heurystycznych. Obiektywny materiał nie tylko wywołuje uczucie, ale również staje się jego treścią. Uczucie sprawia, że każde doświadczenie jest niepowtarzalne.

Powiązanie uczucia ze świadomością i znaczeniem niekoniecznie musi wiązać się z procesem refleksji i interpretacji. Świadomość nie ogranicza się bowiem tylko do tego, co refleksyjne, ale może mieć również nierefleksyjną postać24. W każdym doświadczeniu estetycznym (a zwłaszcza w tzw. czystym) istnieją znaczenia jakościowe odczuwane bez pośrednictwa języka dyskursywnego, na co zwrócił uwagę również Richard Shusterman ${ }^{25}$. Odczute są przede wszystkim jakości przedmiotów, zdarzeń i sytuacji. Znaczenia jakościowe zawsze posiadają zabarwienie emocjonalne, co podkreśla również Mark Johnson ${ }^{26}$. Ważne jest to, że - jak stwierdzają Dewey, Shusterman i Johnson - znaczenia jako-

${ }^{21}$ Koncepcja ta jest zgodna z teorią Jamesa-Langego, według której to nie emocje wywołują zmiany somatyczne i behawioralne, ale zmiany somatyczne i behawioralne poprzez nadanie im znaczenia są interpretowane jako emocja.

${ }_{22}^{2}$ Dewey, Sztuka jako doświadczenie, 84.

${ }^{23}$ Również w Experience and Nature Dewey lokuje uczucia w sytuacji i wiąże je ze znaczeniem. Zob. Dewey, The Later Works: 1925-1953, vol. 1: Experience and Nature (London and Amsterdam, Carbondale, 1969-1990), 198, 292. Zob. też Johnson, Znaczenie ciała, 85-86 oraz Stankiewicz, Estetyka pragmatyczna, 193-194.

${ }^{24}$ Zob. Ziółkowska-Juś, „Świadomość i poznanie integralne”.

${ }_{25}$ Zob. Richard Shusterman, Interpretacja a rozumienie, w: Richard Shusterman, Estetyka pragmatyczna. Żywe piękno i refleksja nad sztuka, przeł. Andrzej Orzechowski (Wrocław: Wydawnictwo Uniwersytetu Wrocławskiego 1998), 154-155.

26 Zob. Johnson, Znaczenie ciała, 86-87. 
ściowe, mimo że mają charakter niedyskursywny (nierefleksyjny), mogą być świadome.

Podsumujmy. U Deweya znajdujemy następujące tezy dotyczące uczuć: 1) w odróżnieniu od warunkujących je odruchów fizjologicznych, uczucia są świadome i intencjonalne; 2) uczucia nie są subiektywne i zamknięte w jaźni, ale wykraczają poza dualizm podmiot-przedmiot; 3) uczucia stanowią warunek nadawania znaczeń, wiążą się z wartościowaniem i ustosunkowaniem do danej sytuacji; 4) uczucia są zawsze konkretne i własne; 5) świadomość uczuć nie musi wiązać się z procesem refleksji.

\section{Natura uczuć w doświadczeniu estetycznym}

Dewey pisze o uczuciach estetycznych, charakterystycznych dla doświadczenia estetycznego ${ }^{27}$. Nie każde uczucie jest uczuciem estetycznym. Uczucia estetyczne zarówno warunkują doświadczenie estetyczne, jak i są w trakcie jego przebiegu wykształcane. Warto zdać sprawę, na czym polega ich swoistość.

Przykładem uczucia estetycznego jest według Deweya poruszenie. Autor Sztuki jako doświadczenia twierdzi, że emocjonalne poruszenie jest warunkiem i początkiem doświadczenia estetycznego. Jest ono możliwe tylko w przypadku dysponowania przez osobę doświadczającą wrażliwością która pod wpływem jakości danego przedmiotu, sytuacji, wydarzenia uaktywnia jej wyobraźnię, nabytą wiedzę i refleksję: „Poruszenie zapoczątkowuje pełne doświadczenie, ponieważ wywodzi się z potrzeby, z głodu i z pragnienia, które dotyczą ustroju jako całości i mogą być zaspokojone jedynie przez ustanowienie określonych stosunków (czynnych zależności i wzajemnych oddziaływań) z otoczeniem"28. Poruszenie Dewey określa również mianem natchnienia: „Być rozpalonym do białości przez myśl czy przez wizję znaczy być natchnionym" ${ }^{\prime 29}$. Potrzeba związana z poruszeniem potwierdza zależność ustroju z otoczeniem, gdyż może być zaspokojona jedynie w związku z tym, co ofiaruje środowisko. Należy jednak dodać, że potrzeba inicjująca doświadczenie estetyczne jest w pewnym sensie bezinteresowna, gdyż nie jest związana

27 Zagadnienie uczuć estetycznych (ang. aesthetic feelings) pojawia się we wczesnej pracy Johna Deweya Psychology. The Early Works, 1882-1898, vol. 2 (London and Amsterdam: Carbondale 1969-1990), 267-280, a zostaje najpełniej rozwinięte w jego ostatniej książce Sztuka jako doświadczenie.

${ }^{28}$ Dewey, Sztuka jako doświadczenie, 73-74.

29 Tamże, 82. 
z chęcią posiadania ani też z odniesieniem doświadczenia do zewnętrznych wobec niego celów ${ }^{30}$.

Na drodze do zaspokojenia potrzeby wywołanej poruszeniem pojawiają się opory i trudności, których pokonywanie w dążeniu do spełnienia rodzi nowy „przedmiot ekspresyjny”. W ujęciu Deweya „przedmiot ekspresyjny" nie musi być rozumiany esencjalnie (jako tzw. artefakt), ale może być ujęty procesualnie. Przedmiotem tym może być samo doświadczenie. Wszelkie opory, napięcia i trudności pojawiające się $\mathrm{w}$ interakcji organizmu z otoczeniem powoduja, że jaźń zyskuje świadomość samej siebie. Dzięki trudnościom i oporom dążenie motywowane potrzebą zostaje w jakiś sposób ukierunkowane i zorganizowane. Konieczność sprostania danej sytuacji sprawia, że pierwotne poruszenie ulega transformacji, nabierając pewnej formy i stałości. Rodzi się proces ekspresyjny, w którym zarówno osoba doświadczająca, jak i doświadczany materiał ulegają przekształceniom.

Uczucie estetyczne stanowi warunek organizacji danego materiału w niepowtarzany "przedmiot ekspresyjny”. Dzięki niemu może dopiero wyłonić się określony kształt „dzieła”, którego elementy łączą się ze sobą w jedną całość, a nie tylko występują jedne po drugich. Uczucie estetyczne wiąże ze sobą $\mathrm{w}$ określony sposób poszczególne elementy dzieła. Sprawia ono, że zakończenie i spełnienie dzieła są przeczuwane w każdym momencie doświadczenia. Nie jest ono częścią składową (treścią) przedmiotu estetycznego, ale go porządkuje, jednoczy i przenika. Przynależy zatem do jego formy. Można powiedzieć, że przedmiot ekspresyjny „przechowuje” towarzyszące jego powstaniu uczucia. Dzięki niemu uczucia estetyczne wkraczają w przestrzeń intersubiektywnej komunikowalności. Sztuka ma charakter selektywny. Artystyczna praca twórcza wymaga nie tylko nagromadzenia doświadczeń, obserwacji i materiałów, ale zwłaszcza wydobycia z nich tego, co ważne, i odrzucania tego, co nieistotne. Wymaga ona odpowiedniego doboru odrębnych przedmiotów i złożenia ich w jeden przedmiot ekspresyjny, który skupia i wyraża wartości właściwe im wszystkim ${ }^{31}$. Ważne $\mathrm{w}$ pracy twórczej jest zarówno uwzględnianie dynamiki ciągle zmieniającego się doświadczenia, jak i jego spójności budowanej wokół krystalizującej się myśli przewodniej.

Doświadczenie jedności dzieła wiąże się z występującą w nim jakością estetyczna, która ma charakter emocjonalny. Jakość estetyczna jest odczuwana intuicyjnie, w bezpośredni sposób. Wiąże ona i przenika wszystkie części dzieła. Bez jakości estetycznej poszczególne części dzieła są powiązane ze sobą tylko mechanicznie albo przypadkowo. Łączy ona ze sobą zróżnicowane i zmienne elementy w jedno dzieło,

30 Dewey, Psychology, 271.

${ }^{31}$ Dewey, Sztuka jako doświadczenie, 85. 
odciskając na nim zarówno piętno indywidualizmu, jak i uniwersali$\mathrm{zmu}^{32}$. Zadaniem uczucia jest uzyskanie ciągłości dzieła oraz jedności efektów w różnorodności, czyli harmonii ${ }^{33}$. Uczucie estetyczne warunkuje doświadczenie twórcze i estetyczne, a także decyduje o jego kształcie, jedności i znaczeniu.

W przeciwieństwie do odruchu, w doświadczeniu estetycznym uczucie nie ma charakteru momentalnego, ale rozwija się i narasta w czasie i przestrzeni: „Prawdziwa istota uczucia ujawnia się w przeżyciach widza w teatrze lub przy czytaniu powieści. Uczucie śledzi rozwijającą się akcję, a ta wymaga widowni, wymaga przestrzeni, aby móc się rozwijać, i czasu, aby narastać" 34 .

Dzięki uczuciu estetycznemu dzieło nabiera świeżości i spontaniczności. Ekspresja artystyczna jest o tyle spontaniczna, o ile łączy nabytą wiedzę z aktualnym doświadczeniem. Uczucie ożywione doświadczanym materiałem odświeża i przywołuje dawne zachowane $\mathrm{w}$ świadomości i podświadomości treści. Dzięki niemu nabierają one posmaku nowości i oryginalności. W doświadczeniu estetycznym to, co stare, i to, co nowe, ulega przekształceniu. $W$ procesie twórczym istotną rolę pełnią zarówno treści świadome, jak i nieświadome. Świadomość odpowiada za uporządkowanie materiału i kontrolowanie przebiegu doświadczenia estetycznego, a dzięki nieświadomości pojawia się tak ważna dla sztuki świeżość i spontanicznośćc 35 .

Dewey podkreśla, że nie każdy rodzaj uczuć i nie każde ich natężenie sprzyja doświadczeniu estetycznemu: ,jeśli ulegamy namiętnościom, na przykład kiedy zostaniemy doprowadzeni do pasji lub ulegamy panice czy zazdrości, wówczas doświadczenie traci zdecydowanie swój estetyczny charakter. Nie odczuwamy w ogóle żadnego związku z jakościami działania, które spowodowało namiętność. Skutkiem tego w materiale doświadczenia brakuje elementów równowagi i proporcji”"36. Czynnikami zakłócającymi twórczą ekspresję są również nadmierna receptywność i nadmierna aktywność. Działanie pobudza, natomiast jego doznawane skutki powodują uspokojenie. Ich równowaga sprawia, że ekspresja jest uporządkowana, a jednocześnie zabarwiona uczuciem. Bez równowagi między doznaniem i działaniem nie ma estetycznej ekspresji. Twórczość artystyczna zostaje utrudniona przez niezwiązane z przedmiotem ekspresji negatywne uczucia, rozproszenie, zbytnie pobudzenie emocjonalne oraz niedomiar uczucia. Rozproszenie uwagi pro-

32 Tamże, 54.

33 Tamże, 87.

34 Tamże, 53.

35 Zob. John Dewey, Jak myślimy, przeł. Zofia Bastgenówna (Warszawa: PWN 1988), 260.

36 Dewey, Sztuka jako doświadczenie, 61. 
wadzi do zestawienia źle dobranych części. Nadmiar uczucia powoduje nieład, przeszkadza w sprecyzowaniu części dzieła i jego wykończeniu, a w krańcowych przypadkach w ogóle uniemożliwia powstanie sztuki: „W rzeczywistości człowiek oszołomiony uczuciem staje się niezdolny do wyrażenia go" ${ }^{\prime 37}$. Natomiast niedomiar uczucia objawia się w oschłości i schematyczności, czyli zbytniej „poprawności” dzieła.

Twórczość artystyczna, chociaż rodzi się z nieokreślonego poruszenia, wymaga ukierunkowania i uporządkowania materiału, a zarazem przekształcenia pierwotnych, nieokreślonych uczuć w uczucia estetyczne. Twórczości sprzyjają tylko takie uczucia, które ożywił nagromadzony i przyswojony materiał. Umożliwiają one: „dobór odpowiedniego słowa, właściwego miejsca dla właściwego zdarzenia, doskonałych proporcji, precyzyjnego tonu, barwy czy odcienia, które sprzyjają zjednoczeniu całości, a jednocześnie precyzują szczegóły" ${ }^{\prime 38}$. Realizacja jedności w różnorodności (harmonii dzieła) nie dokonuje się poprzez podporządkowanie twórczości zewnętrznym regułom, ale właśnie za sprawą uczucia estetycznego ${ }^{39}$. Ekspresja nigdy nie jest prostym i bezpośrednim wyładowaniem uczuć, ale: "zachowywaniem, posuwaniem naprzód rozwoju, wypracowywaniem zakończenia"40. Początkowe uczucie (poruszenie) ulega modyfikacji podczas łączenia się z nowym materiałem: „W miarę jak malarz nakłada farbę na płótno lub wyobraża sobie, jak to będzie wyglądać, również idee i jego uczucia zostają uporządkowane. Gdy pisarz układa swe wątki w słowach, które są właściwym mu środkiem wyrazu, jego idee nabierają dostrzegalnych dlań kształtów" ${ }^{\prime 1}$.

Wskutek przeobrażeń materiałów w akcie ekspresji twórczej wraz z przemianą środowiska zewnętrznego (kamienia, dźwięków, barw, idei i innych) zachodzą również przemiany środowiska wewnętrznego (zachowanych w pamięci obrazów, obserwacji, wspomnień i towarzyszących im uczuć). Budowanie aktu ekspresyjnego polega również na tej „wewnętrznej” przemianie. Zarówno środowisko „wewnętrzne”, jak i „zewnętrzne” wymagają w trakcie aktu ekspresyjnego troskliwej pielęgnacji. Obydwa środowiska są nierozdzielne. Zatem przeobrażenia tego, co „wewnętrzne” i „zewnętrzne”, dokonują się w jednym wspólnym działaniu. Dzięki twórczości artystycznej pierwotne, nieukierunkowane emocjonalne odruchy zostają jakby nasycone świadomością. Naturalne uczucia mogą zostać wysublimowane i rozpoznane dopiero wtedy, kiedy "ujrzą siebie” w powstającym przedmiocie ekspresyjnym. Akt ekspresji włącza to, co surowe, naturalne i nieprzetworzone w nowe

\footnotetext{
37 Tamże, 87.

38 Tamże.

39 Dewey, Psychology, 272.

40 Dewey, Sztuka jako doświadczenie, 77.

41 Tamże, 93.
} 
zależności. Dotyczy to zarówno obiektywnego materiału, jak i uczuć. $\mathrm{W}$ ten sposób wraz z nowym przedmiotem ekspresyjnym rodzą się nowe uczuciowe reakcje.

Warto podkreślić, że akt ekspresyjny nie tłumi pierwotnych uczuć ani też nie przyjmuje ich $\mathrm{w}$ takim kształcie, $\mathrm{w}$ jakim się pojawiaja, ale je konstruktywnie przekształca. Naturalne wyładowanie nagromadzonych energii jest szkodliwe zarówno dla ekspresji artystycznej, jak i dla zachowania rytmu. Równie szkodliwe może być wypieranie uczuć, gdyż pozostając $w$ formie utajonej, mogą one oddziaływać w niechciany i niepożądany sposób. Konstytutywne dla sztuki jest okresowe gromadzenie energii i jej stopniowe (a nie natychmiastowe), przybierające określony kształt artystyczny wyzwalanie: „Opór stawiany natychmiastowemu ujawnianiu się uczuć jest tym, co je zmusza, aby przyjęły kształt rytmiczny" ${ }^{\prime 2}$. Przeciwieństwem uporządkowanego (rytmicznego) rozwoju jest zarówno nieposkromione, niecierpliwe i niezdyscyplinowane wyładowanie energii, jak i jej stłumienie albo rozproszenie (na przykład $\mathrm{w}$ apatii albo jałowych marzeniach).

Uczucia estetyczne, mimo że realizują się w konkretnym miejscu i czasie, mają charakter uniwersalny, gdyż wiążą się z przeczuwaną wartością (ideą), która jest w jakiś sposób ponadczasowa i wykraczająca poza konkretne , ja”. Wcielone w konkretną materię „uczucia estetyczne" stają się intersubiektywnie komunikowalne. W Psychology Dewey akcentuje nieegoistyczną i bezinteresowną naturę uczuć estetycznych. Łączą się one z afirmacją a nie chęcią posiadania przedmiotów. Nie są one nastawione na cel, ale na sam proces tworzenia, drogę do celu, która sama staje się celem. Ta niezależność artystycznej kreacji od zewnętrznych odniesień daje artyście (albo szerzej - twórcy) poczucie wolności $\mathrm{i}$ bycia $\mathrm{w}$ harmonii z samym sobą ${ }^{43}$.

\section{Rola uczuć estetycznych w poznaniu integralnym}

W związku z tym, że poznanie integralne i doświadczenie estetyczne posiadają zbliżoną formę, łączy je rola i charakter występujących w nich uczuć. W poznaniu pojawiają się również innego rodzaju uczucia (na przykład intelektualne), jednak najbardziej interesują nas tu uczucia estetyczne, które przyczyniają się do jego integralności. W kontekście Deweyowskiego pragmatyzmu uczucia estetyczne nie są zarezerwowane wyłącznie dla sztuki, gdyż pojawiają się we wszelkiego rodzaju doświadczeniach (codziennych, poznawczych, moralnych), mających charakter estetyczny. W perspektywie pragmatycznej praca z emocja-

42 Tamże, 189.

43 Zob. Dewey, Psychology. 
mi ma ogromne znaczenie nie tylko dla indywidualnego dobrostanu, pogłębiania relacji interpersonalnych, umiejętności rozwiązywania konfliktów i stawiania czoła trudnym życiowym wyzwaniom, ale również dla kształtowania sfery poznawczej.

Dewey odrzuca założenie o niezależności inteligencji poznawczej od rozwoju uczuć, a także arbitralne przekonanie, że rozwój umysłowy jest ważniejszy i trudniejszy niż rozwój emocjonalny ${ }^{44}$. Rozwój emocjonalny warunkuje rozwój umysłowy i czyni go pełniejszym. W Sztuce jako doświadczeniu czytamy: „Nawet w swych szczytowych osiągnięciach "rozum « nie jest zdolny do całkowitego pojmowania i samowystarczalnej pewności. Musi odwoływać się do wyobraźni, do idei wcielonych w ładunek emocjonalny zmysłów" ${ }^{\prime 4}$. Poznanie intelektualne jest zakorzenione w sferze cielesnej, a każda próba jego odcięcia od źródeł sprawia, że staje się ono zbyt abstrakcyjne, jednostronne, jałowe, dogmatyczne, a w konsekwencji destrukcyjne. Odizolowanie poznania od sfery cielesnej i emocjonalnej jest $\mathrm{w}$ istocie niemożliwe, jednak antagonizowanie obu sfer albo wskazywanie na ich niezależność sprawia, że zepchnięte w sferę nieświadomości uczucia i cielesność zamiast sprzyjać myśleniu mogą manifestować się w niechciany sposób, stanowiąc "blokady" dla myśli. Warunkiem uestetyczniania poznania jest troska nie tylko o umysł, ale również o warunkującą go sferę cielesną i uczuciowa ${ }^{46}$. W poznaniu integralnym istotne jest nie tylko pogłębianie świadomości myślenia, ale również świadomości ciała, zmysłów i uczuć. Sfera intelektualna - co podkreśla nawiązujący do Deweya Shusterman - ma w owej pracy nad sferą cielesną i emocjonalną dużą rolę do odegrania, co zakłada istnienie sprzężenia zwrotnego pomiędzy emocjami i poznaniem ${ }^{47}$. Umysł, który wyewoluował ze sfery cielesnej (zmysłowej, emocjonalnej), może się jej albo przeciwstawić (z czym mamy do czynienia na przykład w poznaniu niepełnym), albo ją pielęgnować i się z nią zintegrować (jak w poznaniu integralnym). Dewey (wraz z innymi pragmatystami, na przykład Shustermanem) wychodzi z obcego kulturze zachodniej założenia, że człowiek działa i istnieje w sposób bardziej twórczy i owocny, gdy

${ }^{44}$ Dewey pisze: „wykonanie prawdziwego dzieła sztuki zapewne stawia wobec inteligencji większe wymagania aniżeli tak zwane myślenie, jakie na ogół uprawiają ci, którzy chełpią się mianem intelektualistów". Dewey, Sztuka jako doświadczenie, 58.

45 Tamże, 43.

46 Zob. Richard Shusterman, Myślenie ciała. Eseje z zakresu somaestetyki, przeł. Patrycja Poniatowska (Warszawa: Instytut Wydawniczy Książka i Prasa, 2016), 59-60.

${ }_{47}$ Również neurolodzy (na przykład Joseph LeDoux, Richard Davidson) podkreślają że nie ma w mózgu jednego ośrodka odpowiedzialnego za powstawanie emocji i procesów poznawczych. Funkcje emocjonalne i poznawcze stanowią wynik złożonych interakcji połączeń neuronowych. Stwierdzają że relacje pomiędzy poznaniem i emocjami są dwustronne. Zob. Ekman, Davidson, Natura emocji. Podstawowe zagadnienia. 
jest bardziej wewnętrznie zintegrowany i może się wszechstronnie rozwijać $^{48}$. Natomiast harmonijnie rozwijające się jednostki tworzą bardziej harmonijne społeczeństwo ${ }^{49}$. Jednak założenie to jest trudne albo wręcz niemożliwe do zrealizowania w kulturze, w której dominują takie cele, jak: wiedza, władza, sława, sukces, uznanie, prestiż i korzyści finansowe. Podobnie jak $\mathrm{w}$ doświadczeniu estetycznym również $\mathrm{w}$ poznaniu integralnym uczucia odgrywają istotne znaczenia. Spróbujmy, odnosząc się do wypowiedzi Deweya, te znaczenia wydobyć.

Poznanie integralne wiąże się z bezpośrednim odczuwaniem jakości emocjonalnych idei, pojęć, słów, przedmiotów. Chociaż idee i pojęcia pełnią w nim funkcję pośrednicząca, można je również odczuwać w bezpośredni sposób. W Sztuce jako doświadczeniu czytamy:

Rozmaite idee różnie się „czuje”, mają one, jak wszystkie inne rzeczy, własne bezpośrednie właściwości jakościowe. Kto w myśli szuka rozwiązania dla jakiegoś skomplikowanego zagadnienia, napotyka na swej drodze, właśnie na skutek tej właściwości idei, wskazówki prowadzące we właściwym kierunku. To jakości idei powstrzymują go, jeśli zbacza z drogi, i popychają go naprzód, kiedy idzie we właściwym kierunku. Są jak czerwone i zielone światła intelektu ${ }^{50}$.

Znaczenia jakościowe, jak podkreśla, nawiązując do Deweya Mark Johnson, nie są w badaniach naukowych emotywnym ozdobnikiem, ale stanowią również źródło znaczeń konceptualnych ${ }^{51}$. Dzięki uczuciom otwierają się nowe horyzonty poznawcze.

Jakości emocjonalne badanych przedmiotów stanowią istotny motyw $\mathrm{w}$ podejmowaniu dociekań intelektualnych. Dewey porównuje pierwsze poruszenia badacza i artysty do ruchów dzikiego zwierzęcia, które zmierza do celu, zdając się na instynkt i działanie zmysłów ${ }^{52}$. Stwierdza, że:

U uczonych, ludzi parających się myśleniem, a więc u tych, których tradycyjnie przeciwstawia się artystom, świadome działanie umysłu i woli nie ma ani w przybliżeniu tego zakresu, jaki im się na ogół przypisuje. Oni też dążą do celu, który rysuje się im niejasno i nieprecyzyjnie, posuwają się po omacku, wabieni przez tożsamość atmosfery emanującej wokół ich obserwacji i refleksji [...]. Zarówno u jednych, jak i drugich, $\mathrm{w}$ zakresie i stopniu, w jakim ich pozycje są porównywalne, występuje

${ }^{48}$ Por. Ziółkowska-Juś, Rola doświadczenia estetycznego w poznaniu integralnym, 239.

49 Por. Dewey, Sztuka jako doświadczenie, 100.

50 Tamże, 145.

51 Zob. Johnson, Znaczenie ciała, 11.

52 Dewey, Sztuka jako doświadczenie, 42. 
zemocjonalizowane myślenie, którego substancję stanowią dostrzeżone, uznane znaczenia i idee ${ }^{53}$.

Pragmatysta proponuje praktykowanie takiego rodzaju poznania, które jest połączone z twórczym niepokojem i niepewnością poszukiwaniem, zaangażowaniem i troską $a^{54}$. Niepewność towarzysząca poznaniu integralnemu wiąże się również z tym, że pewne odkrycia i idee nie są w nim założone z góry, ale wyłaniają się dopiero $\mathrm{w}$ trakcie poszukiwań.

Zdaniem Deweya uczucia porządkują i organizują to, co intelektualne: „pierwiastek bezpośrednio zmysłowy - a uczucie jest rodzajem zmysłu - ma nie tylko skłonność do wchłaniania wszelkiej treści wyobrażeniowej, ale również, poza przypadkami szczególnej dyscypliny narzucanej przez aparat fizykalny, podporządkowuje sobie i przetwarza wszystko, co jest wyłącznie intelektualne" ${ }^{\prime \prime 5}$. Uczucie estetyczne poprzedza intelektualne pojmowanie ${ }^{56}$. Sądzę jednak, że trafniejsza jest teza (wysuwana na przykład przez Shustermana) o sprzężeniu zwrotnym pomiędzy sferą emocjonalną i intelektualna, w myśl której nie tylko uczucia oddziałują na myśli, ale również refleksja może wpływać na uczucia i je modyfikować.

W poznaniu integralnym istotny jest wzgląd nie tylko na to, co ogólne i dające się przyporządkować określonym pojęciom, ale również zwracanie uwagi na emocjonalne jakości estetyczne: „Badacz miewa w myśleniu chwile estetyczne, kiedy jego idee przestają być wyłącznie ideami i zmieniają się w zbiorowe znaczenie przedmiotów" ${ }^{\prime \prime 5}$.

W poznaniu integralnym uczucia estetyczne pełnią rolę selektywną. Dzięki nim dany materiał zostaje zorganizowany w określony sposób. To właśnie w znacznej mierze uczucia decydują o tym, co istotne, a co można odrzucić. Doznawane treści zostają zorganizowane w hierarchię zależną od tego, co absorbuje uwagę badacza i motywuje go do podjęcia działania. W sposobie „wiązania” materiału, a także łączenia posiadanej wiedzy i doświadczenia z nowymi treściami istotną rolę pełni intuicja i wyobraźnia. Dewey pisze, że: „Uniesienia współczesnych fizyków i astronomów wynikają nie tyle z określonej potrzeby zdobycia nie emocjonalnych informacji przydatnych w logicznym rozumowaniu, co z estetycznej potrzeby zaspokojenia wyobraźni" 58 .

Poznanie jest wówczas integralne, kiedy jego przebieg i rezultat przenika estetyczna jakość emocjonalna:

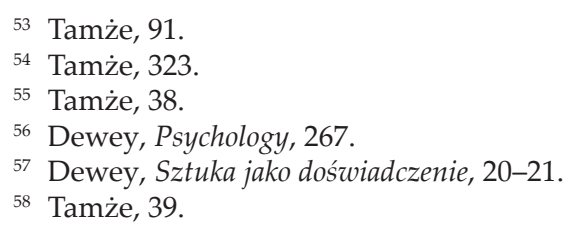


Myślenie przebiega w ciągach pojęciowych, ale pojęcia układają się w takie ciągi tylko dlatego, że są czymś znacznie rozleglejszym od tego, co psychologia analityczna nazywa pojęciami. Są one emocjonalnie i praktycznie wyodrębnionymi fazami rozwijającej się podstawowej jakości. Stanowią jej ruchome odmiany, subtelne odcienie przenikającej i rozkwitającej barwy, a nie oderwane i niezależne tak zwane idee i impresje Locke'a czy Hume'a ${ }^{59}$.

Estetyczna jakość nie odnosi się do cząstkowych celów poznawczych, ale przenika całość intelektualnego procesu ${ }^{60}$.

Poznanie integralne wymaga zdystansowania się wobec negatywnych uczuć, a także uczuć niezwiązanych z badanym przedmiotem. Wymaga ono również względnej równowagi pomiędzy doznaniem (receptywnością) i działaniem. W związku z zaabsorbowaniem jakąś ideą uczucia mogą zostać „wyładowane” zbyt pośpiesznie. Tym samym mogą prowadzić do chaosu i rozproszenia. Drugą skrajnością jest brak zainteresowania, które sprawia, że badacz podąża „utartymi koleinami", kierując się przyzwyczajeniem, co prowadzi do rutyny. Wraz $\mathrm{z}$ organizacją danego materiału uczucia towarzyszące procesowi intelektualnemu przekształcają się w uczucia estetyczne. Zostają one uformowane w spójny rytm, który przenika zarówno przedmiot badań, jak i samego badacza.

Uczucia estetyczne wzbogacają osobę poznająca, przyczyniają się do poczucia harmonii i bardziej owocnych rezultatów ${ }^{61}$. Dzięki nim badacz doświadcza satysfakcji i spełnienia wynikających ze swojej pracy:

Bywają pasjonujące dociekania i spekulacje myślowe, które naukowiec lub filozof wspomina jako „doświadczenia” w podkreślającym znaczeniu tego słowa. Treść ich jest ostatecznie intelektualna, ale w czasie ich trwania miały one również charakter emocjonalny - były celowe i wolicjonalne. [...] Żaden myśliciel nigdy nie może poświęcić się swej pracy, jeśli nie urzekną go i nie wynagrodzą mu trudu takie całościowe integralne doświadczenia, które istotnie są warte zachodu. Bez nich nie wiedziałby nigdy, co naprawdę znaczy myśleć, i stałby bezradny, kiedy przyszłoby odróżnić myśl prawdziwą od fałszywej ${ }^{62}$.

\section{Uwagi końcowe}

Poznanie integralne nie jest czymś danym, ale wymaga kształcenia. Sądzę jednak, że warto je praktykować i do niego dążyć, gdyż przyczynia

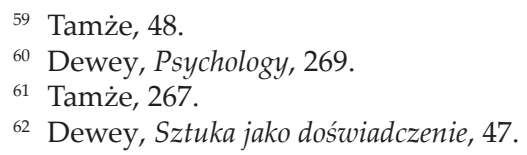


się do integralności i satysfakcji osoby poznającej, a także do owocnych rezultatów poznawczych. Ponadto oddziałuje ono konstruktywnie na otoczenie osoby poznającej. Uważam, że poznanie integralne wymaga przede wszystkim stworzenia warunków harmonijnego rozwoju człowieka $\mathrm{w}$ różnych instytucjach, takich jak szkoły, uniwersytety i inne. Nie współgra z pośpiechem, atmosferą rywalizacji i presją czasową. Wymaga również samokształcenia, obejmującego nie tylko rozwój sfery umysłowej, ale także warunkującej je sfery nierefleksyjnej (cielesnej, zmysłowej, emocjonalnej). Umysł, który wyewoluował ze sfery cielesnej, może albo jej się przeciwstawić, albo ją pielęgnować i dążyć do pozostawania $\mathrm{z}$ nią $\mathrm{w}$ harmonii. $\mathrm{W}$ kontekście estetyki pragmatycznej istotne jest nie tylko teoretyczne skonstatowanie znaczenia uczuć, ale przede wszystkim podjęcie pracy nad ich konstruktywnym przekształcaniem. Praca z emocjami może przybierać zróżnicowaną formę. Dewey pokazuje, że uczucia można kształtować poprzez praktykowanie doświadczenia estetycznego. Sądzę, że jednym z ważniejszych czynników uestetyczniających poznanie mogłoby być przykładanie w nim większej wagi do pielęgnowania doświadczenia estetycznego jako jego integralnej części. Myślę, że naukowcy i filozofowie mogą się w tym zakresie wiele nauczyć od artystów. Uestetycznianie poznania wiąże się zwłaszcza z troską o jego sferę uczuciową. Relacji pomiędzy uczuciami a sferą intelektualną nie określa jedynie jednostronne warunkowanie poznania przez uczucia, ale relacja sprzężenia zwrotnego (uczucia warunkujące procesy umysłowe, sfera poznawcza modyfikująca uczucia). Sądzę, że dzięki uwzględnieniu tej ostatniej tezy możliwe staje się realizowanie pragmatycznego postulatu udoskonalenia doświadczenia, również poznawczego. Uczucia estetyczne są ważne nie tylko dla działalności stricte artystycznej, ale również innego rodzaju doświadczeń, w tym także poznawczych. W kontekście rozważań Deweya praca z emocjami, ich kształtowanie i uestetycznianie stają się istotną częścią integralnego procesu poznawczego.

\section{Bibliografia}

Damasio Antonio. 2000. Błąd Kartezjusza: emocje, rozum i ludzki mózg, przeł. Maciej Karpiński. Poznań: Rebis.

Damasio Antonio. 2000. Tajemnica świadomości: ciało i emocje wspóttworza świadomość, przeł. Maciej Karpiński. Poznań: Rebis.

Damasio Antonio. 2005. W poszukiwaniu Spinozy. Radość, smutek i czujacy mózg, przeł. Janusz Szczepański. Poznań: Rebis.

Dąbrowski Kazimierz (red.). 1981. Zdrowie psychiczne. Warszawa: PWN.

Dewey John. 1969-1990. The Later Works: 1925-1953, vol. 1: Experience and Nature. London and Amsterdam: Carbondale. 
Dewey John. 1969-1990. The Early Works: 1882-1898, vol. 2: Psychology. London and Amsterdam: Carbondale.

Dewey John. 1988. Jak myślimy?, przeł. Zofia Bastgenówna. Warszawa: PWN. Dewey John. 1975. Sztuka jako doświadczenie, przeł. Andrzej Potocki. Wrocław-Warszawa-Kraków-Gdańsk: Zakład Narodowy im. A. Ossolińskich.

Ekman Paul, Richard J. Davidson (red.). 1999. Natura emocji. Podstawowe zagadnienia, przeł. Bogdan Wojciszke. Gdańsk: Gdańskie Wydawnictwo Psychologiczne.

Goleman Daniel. 1997. Inteligencja emocjonalna, przeł. Andrzej Jankowski. Poznań: Media Rodzina.

Greenspan Stanley I., Beryl Lieff Benderly. 2000. Rozwój umystu. Emocjonalne podstawy inteligencji, przeł. Małgorzata Koraszewska. Poznań: Rebis.

Johnson Mark. 2015. Znaczenie ciała: Estetyka rozumienia ludzkiego, przeł. Jarosław Płuciennik. Łódź: Wydawnictwo Uniwersytetu Łódzkiego.

Koczanowicz Dorota. 2008. Doświadczenie sztuki, sztuka życia. Wymiary estetyki pragmatycznej. Wrocław: Wydawnictwo Dolnośląskiej Szkoły Wyższej Edukacji TWP,

LeDoux Joseph. 2000. Mózg emocjonalny. Tajemnicze podstawy życia emocjonalnego, przeł. Andrzej Jankowski. Poznań: Media Rodzina.

Rorty Richard. 2013. Filozofia jako zwierciadło natury, przeł. Michał Szczubiałka. Warszawa: Wydawnictwo KR.

Shusterman Richard. 1998. Estetyka pragmatyczna. Żywe piękno i refleksja nad sztuka, przeł. Adam Chmielewski, Ewa Ignaczak, Leszek Koczanowicz, Łukasz Nysler, Andrzej Orzechowski. Wrocław: Wydawnictwo Uniwersytetu Wrocławskiego.

Shusterman Richard. 2016. Myślenie ciała. Eseje z zakresu somaestetyki, przeł. Patrycja Poniatowska. Warszawa: Instytut Wydawniczy Książka i Prasa.

Shusterman Richard. 2010. Odnowienie somatycznej refleksji. Filozofia ciało umystu Johna Deweya, 239-284. W: Richard Shusterman, Świadomość ciała. Dociekania z zakresu somaestetyki, przeł. Wojciech Małecki, Sebastian Stankiewicz. Kraków: Universitas.

Stankiewicz Sebastian. 2012. Estetyka pragmatyczna-projekt otwarty. Kraków: Universitas.

Welsch Wolfgang. 2005. Estetyka poza estetyka. O nowa postać estetyki, przeł. Katarzyna Guczalska. Kraków: Universitas.

Wilkoszewska Krystyna. 2003. Sztuka jako rytm życia. Rekonstrukcja filozofii sztuki Johna Deweya. Kraków: Universitas.

Ziółkowska-Juś Anna. 2016. „Rola doświadczenia estetycznego w poznaniu integralnym. Ku Deweyowskim inspiracjom". Estetyka i Krytyka 42, 3: 219-244.

Ziółkowska-Juś Anna. 2018. „Świadomość i poznanie integralne. W kręgu inspiracji pragmatyzmem Johna Deweya". Filo-Sofija 43, 4: 37-55. 


\section{Streszczenie}

Celem niniejszego artykułu jest omówienie roli uczuć estetycznych (specyficznych dla doświadczenia estetycznego) w poznaniu integralnym z punktu widzenia pragmatyzmu Johna Deweya. Zaproponowana koncepcja poznania integralnego wymaga zjednoczenia intelektu ze zmysłami, uczuciami, cielesnością oraz wyobraźnią i intuicja, czyli sferą estetyczną. Praktykowanie tego rodzaju poznania prowadzi do zdobywania informacji i holistycznego rozwoju człowieka, osiągnięcia przezeń wewnętrznej harmonii i satysfakcji. Pierwsza część artykułu dotyczy związku doświadczenia estetycznego z poznaniem integralnym. Druga część przedstawia znaczenie uczuć w postawie pragmatycznej Deweya. Trzecia część analizuje specyfikę uczuć estetycznych. Ostatnia część ma na celu rozważenie, w jaki sposób i dlaczego uczucia estetyczne przyczyniają się do poznania integralnego.

Słowa kluczowe: uczucia estetyczne, poznanie integralne, doświadczenie estetyczne, estetyka pragmatyczna

\section{Aesthetic Feelings and Integral Knowledge. Considerations Based on John Dewey's Pragmatic Aesthetics}

\section{Summary}

The aim of this article is to discuss from the perspective of John Dewey's pragmatism the role of aesthetic feelings (specific for aesthetic experience) in integral knowledge. The proposed concept of integral knowledge requires the unification of the intellect with the senses, feelings, corporeality, and imagination and intuition that is the aesthetic sphere. Practising this type of knowledge leads to acquiring information and the holistic development of the human being, the inner harmony and satisfaction. The first part of the article deals with the connection between aesthetic experience and integral knowledge. The second part presents the meaning of the feelings in Dewey's pragmatic attitude. The third part analyses the specificity of aesthetic feelings. The last part aims to consider how and why aesthetic feelings make knowledge integral.

Keywords: aesthetic feelings, integral knowledge, aesthetic experience, pragmatic aesthetics 